\title{
STUDY ON CLINICAL PROFILE, COMPLICATIONS AND OUTCOME OF COPPER SULPHATE POISONING AT A TERTIARY CARE CENTRE IN SOUTH INDIA
}

\author{
Vasanthi Perumal1, Namitha Narayanan², Jagadeshan Mohanan³, Jayanthi Rangarajan4, Mohamed Kalifa 5 , Uma Maheshwari \\ Perincheri6, Elangumanan Palanisamy7, Pravin Selvam Selvaraj ${ }^{8}$
}

\begin{abstract}
${ }_{1}^{1}$ Associate Professor, Department of Internal Medicine, Govt. Stanley Medical College \& Hospital, Chennai. ${ }^{2}$ Assistant Professor, Department of Internal Medicine, Govt. Stanley Medical College \& Hospital, Chennai. ${ }^{3}$ Senior Resident, Department of Internal Medicine, Govt. Stanley Medical College \& Hospital, Chennai. ${ }^{4}$ Professor, Department of Internal Medicine, Govt. Stanley Medical College \& Hospital, Chennai.

${ }^{5}$ Assistant Professor, Department of Internal Medicine, Govt. Stanley Medical College \& Hospital, Chennai. 6Junior Resident, Department of Internal Medicine, Govt. Stanley Medical College \& Hospital, Chennai. 7Junior Resident, Department of Internal Medicine, Govt. Stanley Medical College \& Hospital, Chennai. 8Junior Resident, Department of Internal Medicine, Govt. Stanley Medical College \& Hospital, Chennai.
\end{abstract}

\section{ABSTRACT}

\section{BACKGROUND}

Copper Sulphate ingestion is a relatively common method of committing suicide in South India. It can be life-threatening with high mortality due to its deleterious effects on upper GIT, kidney, liver and blood.

\section{AIM}

To analyse the clinical profile, complications and outcome of patients admitted with alleged Copper Sulphate poisoning in intensive medical care unit at Govt. Stanley Medical College Hospital.

\section{SETTINGS AND DESIGN}

A prospective observational study.

\section{MATERIALS AND METHODS}

Study was carried out at the Toxicology Unit of Intensive Medical Care Unit and Medical Wards of Govt. Stanley Hospital, Chennai, from August 2011 to November 2013. All patients above the age of 13 years were included in this study. Patients admitted with mixed poisoning, liver and kidney diseases, bleeding disorders were all excluded from this study.

\section{RESULTS}

Of the 60 patients studied, 37 were females and 27 were males. Mode of poisoning was suicidal in 58 patients and accidental in 2 patients. Mean age in males was 31.24 years and in females 25.52. In this study group, 32 were married and 28 were unmarried. The frequency of symptoms the patients presented with decreasing frequency were vomiting (21), icterus (15), abdominal pain (14), cyanosis (8) and oliguria (4).

\section{CONCLUSIONS}

Copper sulphate poisoning presenting with fulminant hepatitis has 26 times more chance of death (P value 0.0008), acute kidney injury 17 times more chance of death (P value 0.0006), Gastritis by upper GI endoscopy has 7 times more chance of death (P value $0.01)$.

\section{KEYWORDS}

Copper Sulphate, Oral Ingestion, Suicidal, Fulminant Hepatitis, Acute Kidney Injury.

HOW TO CITE THIS ARTICLE: Perumal V, Narayanan N, Mohanan J, et al. Study on clinical profile, complications and outcome of copper sulphate poisoning at a tertiary care centre in South India. J. Evolution Med. Dent. Sci. 2016;5(52):3440-3444, DOI: $10.14260 /$ jemds/2016/794

\section{INTRODUCTION}

Copper sulphate is one of the salts of copper. It is odourless, blue in colour. This salt is used in the making of various types of insecticides, herbicides, fungicides and algaecides. Copper sulphate toxicity can present as asymptomatic to lifethreatening complications and death, based on the amount of copper sulphate ingested.

Financial or Other, Competing Interest: None.

Submission 05-05-2016, Peer Review 08-06-2016,

Acceptance 13-06-2016, Published 30-06-2016.

Corresponding Author:

Vasanthi Perumal,

36, Sunkuvar Street,

Triplicane,

Chennai - 600005 .

E-mail: medipubs@gmail.com

DOI: $10.14260 /$ jemds/2016/794
The toxic effects of copper sulphate poisoning is enumerated by various case studies and case reports. This study is about the clinical profile and the outcome of patients with copper sulphate poisoning. Copper is one of the essential trace elements in humans. It is used in various industries like painting, leather, utensil manufacturing, electrical, gold jewellery, etc.

In the serum, Copper is present in two forms mainly bonded with ceruloplasmin $93 \%$ and other is bonded with albumin 7\%. The copper-albumin complex is responsible for the toxicity in the case of acute poisoning. Copper is transported with ceruloplasmin and stored in tissues as metallothionein.

Copper toxicity mainly affects the erythrocytes, hepatic system and renal system.[1] The pathogenesis of copper 
toxicity mainly arises by its damage to the red cell membrane and inactivation of enzymes by its pro-oxidant.[2] nature, which leads to intravascular haemolysis and haemolytic anaemia. Hepatic damage is either due to direct effect or due to haemolysis.[1]

The main pathogenesis in renal failure is intravascular haemolysis, which leads to acute kidney injury. Corrosive effect of copper sulphate results in ulcer in oesophagus, stomach and intestines, which can cause acute gastritis, intestinal haemorrhage, necrosis and perforation. Other features include hypotension, sinus tachycardia, cardiac arrhythmias, convulsions, rhabdomyolysis, myoglobinuria.

\section{TREATMENT}

The mainstay of treatment is prevention of absorption and deposition of copper in tissues which in turn depends upon early admission in hospital and removal of toxin and maintenance of intravascular volume by fluid therapy. Copper chelators can be used in severe poisoning like dimercaprol, Dpenicillamine, British Anti-Lewisite (BAL), Ethylene Diamine Tetra Acetate (EDTA). There is no clear studies mentioning the effectiveness of chelators in humans for acute copper toxicity. The management and the treatment of copper sulphate poisoning patients are mainly done by the following entities.

A. Methods to reduce absorption.

B. Supportive care.

1. Management of corrosive burns.

2. Treatment of Methaemoglobinaemia.

3. Managing hypotension.

4. Management of rhabdomyolysis.

C. Chelation therapy.

D. Methods to enhance excretion.

\section{METHODS TO REDUCE ABSORPTION}

Most of the authors recommend treatment to prevent vomiting, as it may cause recurrent corrosive injury to oesophagus.[3] In copper sulphate toxicity, patients tend to have vomiting instantaneously, therefore antiemetic drugs must be given to them.[4]

The absorption of copper can also be reduced by giving activated charcoal. But it is mainly used in excess ingestion, which is expected to be fatal.[5] The usefulness of activated charcoal is not very evident, but is tried as it is not toxic and can have some absorptive capacity.[4]

The dose of activated charcoal is usually 25-100 gram in adult that is 1 gram $/ \mathrm{kg}$. It is given orally and it is useful when given within an hour of intake of copper sulphate. For every 30 gram of charcoal, $250 \mathrm{~mL}$ of water is added.

Another way of reducing the absorption of copper sulphate is early administration of egg white.

\section{SUPPORTIVE MEASURES}

\section{Management of Corrosive Burns}

Whenever a patient is admitted with copper sulphate poisoning, an upper GI endoscopy must be performed to assess the gastric and oesophageal injury and severity. Usually, it is done before 24 hours.[6][7][8] These guidelines are taken from the studies of patients with corrosive ingestion.

Early upper GI endoscopy is proved to be relatively safe in patients with corrosive intake. In a study of 94 cases with corrosive ingestion, 81 cases underwent GI endoscopy within
24 hours and 12 cases within 48 hours. It was uneventful with no adverse effects.[7]

Like the above case study, yet another study showed no complications in patients who had endoscopy within 24 hours. The total number of cases were 16, of which 13 underwent the procedure within 24 hours. Moreover, the study stated that early endoscopy was useful in assessing the severity of the injury, and treating the patient and for the prognosis.[8]

Gupta et al showed in a case series of 26 cases with copper sulphate ingestion who were given steroids and reported that the mortality was less in those patients who received corticosteroids. ${ }^{[9]}$ But this was not studied by any other randomized controlled case study, so steroids are not under the guidelines in management.

\section{Methaemoglobinaemia}

The commonest effect of copper sulphate toxicity is cyanosis. It is due to methaemoglobinaemia. It is treated by giving methylene blue intravenously, whenever serum methaemoglobin increases more than $20 \%$; it can even occur at low range in patients who have the following disorder.

- Anaemia.

- Pulmonary disease.

- Cardiovascular disease.

Along with methylene blue, oxygen must also be given.

\section{Dose}

$1-2 \mathrm{mg} / \mathrm{kg} /$ dose given intravenously for 5 minutes. It can be given once again if cyanosis persists for an hour. Usually, cyanosis disappears by 40 minutes. This is due to decreasing the half-life of methaemoglobin by methylene blue.

\section{Hypotension}

One of the dangerous clinical feature, which can go unnoticed is hypotension. This feature makes necessary the measurement of blood pressure and pulse frequently.

Hypotension can be managed by,

- Adequate hydration by intravenous fluids.

- Intravenous dopamine

- Intravenous noradrenaline.

Hypotension was mainly due to loose stools, vomiting or gastrointestinal bleeding. In the background of critically ill and sepsis, adrenal insufficiency can occur. But there is no evidence that copper sulphate poisoning can cause adrenal insufficiency directly.

\section{Rhabdomyolysis}

Rhabdomyolysis is also an important complication that may lead to acute kidney injury. The following management prevents the occurrence of this adverse effect of copper toxicity.

- Early and adequate fluid therapy. The amount of fluid replaced is about 4-6 litres per day. Extreme care must be taken, so that patient do not have fluid overload.

- Intravenous mannitol.

- Alkalinisation of urine by forced alkaline diuresis must be started early and soon after the admission.

The efficacy of these therapeutic measures are clinically not evident.[10] 


\section{Chelation Therapy}

Chelation therapy is mainly used in severe copper sulphate poisoning. The efficacy of chelators is mainly studied from animals. At present, there is no clear studies mentioning the effectiveness of chelators in humans for acute copper toxicity. The following chelators are used for copper sulphate toxicity. They are,

- British Anti-Lewisite (BAL),

- D-penicillamine,

- 2,3-dimercapto-1-propane sulfonate, Na+ (DMPS) and

- $\quad$ Ethylene Diamine Tetra Acetate (EDTA).

If the patient develops acute kidney injury, the use of these chelators can cause more toxicity.

\section{Penicillamine}

One of the most commonly used copper chelator is Dpenicillamine. It is mainly used in acute intoxication. But the evidence for its effectiveness are lacking.[11][12][13] The dose given for adults are 1000 to $1500 \mathrm{mg}$ /day in divided doses. The dose given to paediatric patients is $10 \mathrm{mg} / \mathrm{kg} / \mathrm{day}$, which can be increased up to $30 \mathrm{mg} / \mathrm{kg} /$ day.

A study showed that up to one gram/day can be given based on the adverse effects and toxicity on the patients.[14]

The adverse effects are,

- Proteinuria,

- Haematuria,

- Acute kidney injury,

- Pancytopenia,

- Liver toxicity,

- Contraindicated in patients who are allergic to penicillin.

\section{Dimercaprol/British Anti-Lewisite (BAL)}

Another important chelator, which is used in patients with severe emesis where oral administration of D penicillamine is not possible is BAL. It is administered intramuscularly. It forms a complex with copper and is excreted by bile. Therefore, it can be used in kidney injury. But its effectiveness is not that much when compared to D penicillamine.

\section{Dose}

3 to $5 \mathrm{mg} / \mathrm{kg} /$ dose, 4 th hourly for two days and then 12 th hourly for 7 days.[13][15][16]

\section{Administration}

Deep intramuscularly.

\section{Adverse Effects}

- Pruritus,

- Urticaria, and

- Hyperpyrexia.

\section{Edetate Calcium Disodium}

This is another chelator that can be used in acute copper sulphate poisoning.

\section{Dose}

$75 \mathrm{mg} / \mathrm{kg} /$ day. Should not cross $500 \mathrm{mg} / \mathrm{kg}$.

\section{Administration}

Intramuscular or slow intravenous infusion.

\section{Duration}

5 days.

\section{Adverse Effects}

- $\quad$ Renal tubular acidosis.[15]

\section{Methods to Enhance Excretion}

The methods used to increase or enhance the excretion are,

a. Haemodialysis.

b. Peritoneal dialysis.

c. Haemoperfusion and haemodiafiltration.

Excreting copper from humans intoxicated with copper sulphate by haemodialysis is not useful. But it is useful in the treatment of acute kidney injury due to copper toxicity.[12][17]

Another method used is peritoneal dialysis. But the dialysate must be of salt-poor albumin. The dialysate with saltlow albumin ended in removing high amount of copper. But the quantity extracted by peritoneal dialysis was low.[18] The effectiveness in removal of copper by heme perfusion and haemodiafiltration is still not clear and precise evidence is not available.[19]

\section{AIMS AND OBJECTIVES}

Prospective observational study to analyse the clinical profile, complications, outcome of patients admitted with alleged copper sulphate poisoning in intensive medical care unit at Stanley Medical College Hospital.

\section{MATERIALS AND METHODS}

Place of Study

This study was carried out at the Toxicology Unit of Intensive Medical Care Unit and Medical Wards of Govt. Stanley Hospital, Chennai.

\section{Study Period}

From August 2011 to November 2013.

\section{Study Design}

Prospective observational study.

\section{Ethical Committee Approval}

The Ethical Committee Approval was obtained for this study.

\section{Inclusion Criteria}

1. Any patient admitted with copper sulphate poisoning.

2. Age of the patients $>13$ years.

\section{Exclusion Criteria}

1. Mixed poisons.

2. Patients with liver disease.

3. Patients with kidney disease.

4. Patients on drugs like anticoagulants, antiplatelets.

5. Patients with bleeding disorders or other haematological disorders.

6. Patients with peptic ulcer disease.

\section{Consent}

The study group thus identified by the above criteria (Inclusion and exclusion criteria) was first instructed about the nature of the study. Willing participants were taken up for this study after getting a written/informed consent from these patients or their relatives in the local vernacular language.

\section{Study Subjects}

All the patients who fulfilled the inclusion criteria above 13 years of age and both genders were included in this study. The included patients were subjected to detailed history taking, 
complete physical examination and the relevant laboratory investigations as per proforma, exclusively designed for the study.

The details of the amount of copper sulphate ingested were collected from the patients or their relatives.

\section{RESULTS, OBSERVATION AND DISCUSSION}

This study includes a total number of 60 patients. The basic demographic and frequencies of variables were tabulated in Table.

\begin{tabular}{|c|c|c|c|}
\hline $\begin{array}{l}\text { Sl. } \\
\text { No. }\end{array}$ & Index & Categories & $\begin{array}{c}\text { Frequen } \\
\text { cies }\end{array}$ \\
\hline \multirow[t]{3}{*}{1} & $\operatorname{Sex}(n=60)$ & & \\
\hline & & Male & 23 \\
\hline & & Female & 37 \\
\hline \multirow[t]{3}{*}{2} & $\begin{array}{l}\text { Age (Mean in } \\
\text { Years) }\end{array}$ & & \\
\hline & & Male & $\begin{array}{l}31.24 \\
\text { years }\end{array}$ \\
\hline & & Female & $\begin{array}{l}25.52 \\
\text { years }\end{array}$ \\
\hline \multirow[t]{3}{*}{3} & $\begin{array}{c}\text { Marital Status } \\
(\mathrm{n}=60)\end{array}$ & & \\
\hline & & Unmarried & 28 \\
\hline & & Married & 32 \\
\hline \multirow[t]{3}{*}{4} & $\begin{array}{c}\text { Mode of } \\
\text { poisoning }(n=60)\end{array}$ & & \\
\hline & & Suicidal & 58 \\
\hline & & Accidental & 2 \\
\hline \multirow[t]{7}{*}{5} & $\begin{array}{c}\text { Frequency of } \\
\text { symptoms }\end{array}$ & & \\
\hline & & Icterus & 15 \\
\hline & & UGI lesions & 23 \\
\hline & & Vomiting & 21 \\
\hline & & Abdominal pain & 14 \\
\hline & & Oliguria & 4 \\
\hline & & Cyanosis & 8 \\
\hline \multirow[t]{7}{*}{6} & Complications & & \\
\hline & & $\begin{array}{c}\text { Raised INR } \\
\text { without bleed }\end{array}$ & 17 \\
\hline & & $\begin{array}{l}\text { Raised INR with } \\
\text { bleed }\end{array}$ & 3 \\
\hline & & Acute hepatitis & 13 \\
\hline & & $\begin{array}{c}\text { Fulminant } \\
\text { hepatitis }\end{array}$ & 3 \\
\hline & & AKI & 6 \\
\hline & & $\begin{array}{l}\text { Haemolytic } \\
\text { anaemia }\end{array}$ & 3 \\
\hline \multirow[t]{2}{*}{7} & Treatment & & \\
\hline & & $\begin{array}{c}\text { Use of methylene } \\
\text { blue }\end{array}$ & 9 \\
\hline \multirow[t]{2}{*}{8} & Outcome & & \\
\hline & & Death & 6 \\
\hline
\end{tabular}

Table 2 shows the Various Variables with their Association to Death with Odds ratio and $P$ - value.

\begin{tabular}{|c|c|c|c|c|}
\hline $\begin{array}{l}\text { Sl. } \\
\text { No. }\end{array}$ & Index & $\begin{array}{l}\text { Odds } \\
\text { Ratio }\end{array}$ & $\begin{array}{c}\text { Risk } \\
\text { Rati } \\
\text { o }\end{array}$ & $\begin{array}{c}\mathbf{p} \\
\text { value }\end{array}$ \\
\hline 1 & Male sex & 3.43 & & 0.24 \\
\hline 2 & Married & 1.8 & & 0.49 \\
\hline 3 & $\begin{array}{l}\text { Raised INR without } \\
\text { bleed }\end{array}$ & 0 & & NA \\
\hline 4 & $\begin{array}{l}\text { Raised INR with } \\
\text { bleed }\end{array}$ & 5.2 & 3.8 & 0.17 \\
\hline 5 & Acute hepatitis & 0 & & NA \\
\hline 6 & Fulminant hepatitis & 26 & 10 & $\begin{array}{c}0.000 \\
8\end{array}$ \\
\hline 7 & AKI & 17 & 9 & $\begin{array}{c}0.000 \\
6\end{array}$ \\
\hline 8 & Haemolytic anaemia & 0 & & NA \\
\hline 9 & Icterus & 3.6 & & 0.132 \\
\hline 10 & Gastritis in OGD & 7 & & 0.01 \\
\hline 11 & $\begin{array}{l}\text { Use of methylene } \\
\text { blue }\end{array}$ & 19 & & $\begin{array}{c}0.000 \\
2\end{array}$ \\
\hline \multicolumn{5}{|c|}{$\begin{array}{c}\text { Table 2: Odds Ratio for Variables Leading } \\
\text { to Death with P-Value }\end{array}$} \\
\hline
\end{tabular}

One-Sample T Test Mean Age of Sample with Mean Age of Death.

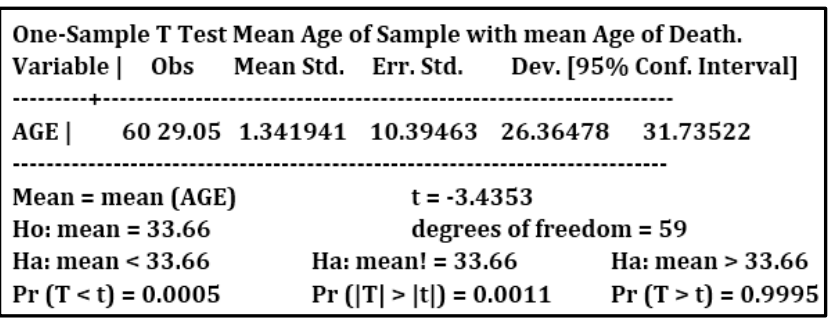

One sample T-test with null hypothesis of mean age of sample and mean age of death is equal, was rejected with $P$ value of 0.0011 . The mean age of death was more than the mean age of population with P-value of 0.0005 .

\section{DISCUSSION}

The mean age of subjects included in this study was 28.38 years, whereas the mean age of subjects was $29.18 \pm 10.77$ in Naha et al study.

The most common symptom in our study and in Naha et al study.[20] was vomiting.

The common complications in our study were Acute hepatitis, Acute kidney injury, GI bleeding similar to Ahasan et al study.[21]

Mortality in our study group was less than $10 \%$, whereas in Naha et al study the mortality was $22.9 \%$, Ahasan et al study mortality was $24.1 \%$.

\section{CONCLUSIONS}

The older the age of patients they have more chances of death. Males have 3 times more chances of death without significant association of P-value (0.24).

Married have 2 times more chances of death without significant association of P-value (0.49).

Fulminant hepatitis has 26 times more chances of death with significant association of P-value (0.0008). 
Acute kidney injury has 17 times more chances of death with significant association of P-value (0.0006).

Involvement of gastritis by upper GIT endoscopy has 7 times more chances of death with significant association of Pvalue (0.01).

Usage of methylene blue for cyanosis has 19 times more chances of death with significant association of $\mathrm{P}$-value (0.002).

\section{REFERENCES}

1. Singh MM, Singh G. Biochemical changes in blood in cases of acute copper sulphate poisoning. J Indian Med Assoc 1968;50(12):549-54.

2. Mital VP, Wahal PK, Bansal OP. A study of erythrocytic glutathione in acute copper sulphate poisoning. Indian J Pathol Bacteriol 1966;9(2):155-62.

3. Rao RB, Hoffman RS. Caustics and batteries. In: Goldfrank LR, Flomenbaum NE, Lewin NA, eds. Goldfrank's toxicologic emergencies. $7^{\text {th }}$ ed. New York: McGraw-Hill, 2002:1326.

4. Nelson LS. Copper. In: Goldfrank LR, Flomenbaum NE, Lewin NA, eds. Goldfrank's toxicologic emergencies. $7^{\text {th }}$ ed. New York: McGraw-Hill 2002:1262-71.

5. Chyka PA, Seger D. Position statement: single-dose activated charcoal. American academy of clinical toxicology; European association of poisons centres and clinical toxicologists. J Toxicol Clin Toxicol 1997;35(7):721-41.

6. Crain EF, Gershel JC, Mezey AP. Caustic ingestions: symptoms as predictors of oesophageal injury. Am J Dis Child 1984;138(9):863-5.

7. Di Costanzo J, Noirclerc M, Jouglard J, et al. New therapeutic approach to corrosive burns of the upper gastrointestinal tract. Gut 1980;21(5):370-5.

8. Dilawari JB, Singh S, Rao PN, et al. Corrosive acid ingestion in man-a clinical and endoscopic study. Gut 1984;25(2):183-7.

9. Gupta PS, Bhargava SP, Sharma ML. Acute copper sulphate poisoning with special reference to its management with corticosteroid therapy. J Assoc Physicians India 1962;10:287-92.
10. Hellmann DB, Stone JH. Arthritis and musculoskeletal disorders. In: Tierney LM, McPhee SJ, Papadakis MA, eds. Current medical diagnosis and treatment. $45^{\text {th }}$ ed. New York: McGraw Hill's 2006:843-4.

11. Jantsch W, Kulig K, Rumack BH. Massive copper sulphate ingestion resulting in hepatotoxicity. J Toxicol Clin Toxicol 1985;22(6):585-8.

12. Howland MA. Methylene Blue. In: Goldfrank LR, Flomenbaum NE, Lewin NA, eds. Goldfrank's toxicologic emergencies. $7^{\text {th }}$ ed. New York: McGraw-Hill 2002:14501.

13. Hantson P, Lievens M, Mahieu P. Accidental ingestion of a zinc and copper sulphate preparation. J Toxicol Clin Toxicol 1996;34(6):725-30.

14. Benitz WE, Tatro DS. The Paediatric Drug Handbook. 3rd ed. St. Louis: Mosby-Year Book Inc, 1995.

15. Walsh FM, Crosson FJ, Bayley M, et al. Acute copper intoxication. Am J Dis Child 1977;131(2):149-51.

16. Fairbanks VF. Copper sulphate-induced haemolytic anaemia. Inhibition of glucose-6-phosphate dehydrogenase and other possible aetiologic mechanisms. Arch Intern Med 1967;120(4):428-32.

17. Agarwal BN, Bray SH, Bercz P, et al. Ineffectiveness of haemodialysis in copper sulphate poisoning. Nephron 1975;15(1):74-7.

18. Cole DE, Lirenman DS. Role of albumin-enriched peritoneal dialysate in acute copper poisoning. J Paediatr 1978;92(6):955-7.

19. Takeda T, Yukioka T, Shimazaki S. Cupric sulphate intoxication with rhabdomyolysis, treated with chelating agents and blood purification. Intern Med 2000;39(3):253-5.

20. Naha K, Saravu K, Shastry BA. Blue vitriol poisoning: a 10 year experience in tertiary care hospital. Clin Toxicol (Phila) 2012;50(3):197-201.

21. Ahasan HA, Chowdhury MA, Azar MA, et al. Copper sulphate poisoning. Trop Doct 1994;24(2):52-3. 